\title{
Tax Paying Compliance After The Issued of Government Regulation Number 23 of 2018 in Belopa City, Luwu Regency
}

\author{
Safruddin ${ }^{1}$, Idayanti Nuryamsi ${ }^{2}$, Muhammad Sobarsyah ${ }^{3}$, Andi Reni Syamsuddin ${ }^{4}$ \\ \{safruddin.pajak@gmail.com ${ }^{1}$,idayanti@unhas.ac.id², msobarsyah@unhas.ac.id², \\ andirenireni@gmail.com ${ }^{4}$, \\ Universitas Hasanuddin, Makassar, Indonesia ${ }^{1-4}$
}

\begin{abstract}
This study aims to analyze the effect of knowledge and understanding, awareness, socialization, and justice on tax-paying compliance after the issued of Government Regulation Number 23 of 2018. The population in this study was 1,489 individual entrepreneur taxpayers in Belopa City, Luwu Regency. The sampling technique using Slovin formula with an error limit of $10 \%$ (ten percent) to get 100 samples of taxpayers. The research approach using quantitative and qualitative approaches. While data analysis using multiple regression analysis techniques. The results showed that knowledge and understanding of taxpayers, awareness of taxpayers, and socialization held by the Government had a positive and significant effect on taxpaying compliance. However, justice in regulation did not have a positive and significant effect on tax-paying compliance after the issued of Government Regulation Number 23 of 2018 in Belopa City, Luwu Regency.
\end{abstract}

Keywords: Knowledge and understanding, awareness, socialization, justice, tax-paying compliance.

\section{Introduction}

Indonesia is a country that is still dependent on state funding from the taxation sector. The government relies heavily on tax revenues to finance various planned developments. In addition, through taxes, the government can improve the welfare of its people. With taxes, the Government can finance infrastructure development, education costs, health costs, fuel subsidies, construction of public facilities, civil servants' salaries, and finance public facilities like roads, bridges, health centers/hospitals, police stations, and so on. All of that is funded by taxes sourced from taxpayer payments. Taxes collected by the Government are carried out on the basis of the applicable laws and regulations.

The Indonesian taxation system, in particular, income tax is known as the term income tax subject, income tax object, and the procedures for imposing income tax rates. Tax subjects are individuals or legal entities that have taxation rights and obligations in accordance with the provisions of the applicable tax legislation while the income tax object is income itself which is any additional economic ability of the tax subject that can add wealth and can be used for consumption both from abroad and from within the country.

For the imposition of current income tax rates, there are 2 (two) types of methods for determining the amount of income tax payable, first, by using general provisions in accordance with the income tax law. The method of calculation starts from determining the 
amount of business circulation, then calculating net income. After that, net income is reduced by Non-Taxable Income according to the marital status and dependents of the taxpayer. The results of this reduction are taxable income that will be subject to progressive tax rates ranging from $5 \%$ (five percent) to $30 \%$ thirty percent).

In addition to the calculation procedure in accordance with the general provisions that are not final, there is also the calculation of final income tax payable sourced from the business. In this calculation, the amount of income tax payable is calculated by multiplying the amount of gross business circulation with the tax rate without any calculation of net income and without any reduction in non-taxable income. This method was introduced since July 1, 2013, with the issuance of Government Regulation Number 46 of 2013.

Furthermore, as a result of evaluating the implementation of Government Regulation Number 46 of 2013, new provisions were issued, which became the basis for calculating final income tax on income from a business, namely Government Regulation Number 23 of 2018. Government Regulation Number 23 of 2018 concerning Income Taxes on Income from Businesses Received or Obtained by Taxpayers with a Specific Gross Distribution is one of the bases for tax collection in Indonesia. This regulation only targets taxpayers with a total gross circulation of up to 4.8 billion in one year. Another interesting thing and the first time this has happened in the taxation system in Indonesia is that with the enactment of Government Regulation Number 23 of 2018 as of July 1, 2018, taxpayers can choose to use the provisions in accordance with the Government Regulation Number 23 of 2018 or to use general provisions in accordance with the Income Tax Law in determining the amount of income tax payable on income from the business received.

The Government Regulation Number 23 of 2018 has the most influence on taxpayers registered at the Tax Office domiciled in small cities with relatively small economic levels. One example is the taxpayer registered at Palopo tax Office located on Jalan Andi Djemma No. 131 Palopo City. The Palopo Tax Office's working area covers 6 (six) regions, namely Palopo City, Luwu Regency, North Luwu Regency, East Luwu Regency, Tana Toraja Regency, and North Toraja Regency where most of the people have income from businesses such as trade, services, and home industries.

The object of research in this study is the Entrepreneur Taxpayers in the City of Belopa, the capital of Luwu Regency. The level of tax-paying compliance by taxpayers in the City of Belopa is as follows:

Table 1. Registered Individual Taxpayers in the City of Belopa

\begin{tabular}{lccccc}
\hline \multirow{2}{*}{ No } & \multirow{2}{*}{ District } & & \multicolumn{2}{c}{ Entrepreneur Taxpayer } & Percentage \\
& & & & & \\
& & Registered & Payment & Non-Payment & \\
\hline 1 & Belopa & 796 & 296 & 500 & $37.19 \%$ \\
2 & North Belopa & 693 & 270 & 423 & $38.96 \%$ \\
& Total & 1,489 & 566 & 923 & $38.01 \%$ \\
\hline
\end{tabular}

As seen in Table 1, the level of compliance for Belopa District was only $37.19 \%$, and North Belopa District was only $38.96 \%$, which overall was only $38.01 \%$ for Belopa City. Measuring the level of taxpayers' compliance can be seen from the receipt of tax return, both the Monthly Income Tax Return and / or Annual Income Tax Return. However, what is used in this research is the submission of the Monthly Income Tax Return because in accordance 
with Government Regulation Number 23 of 2018, taxpayers who make tax payments are considered to have submitted the Monthly Income Tax Return. The low level of tax-paying compliance can be influenced by many things, including knowledge and understanding of tax regulations by taxpayers, awareness of taxpayers as citizens, socialization conducted by the government, and the principle of justice in a regulation.

Knowledge of taxation is not only an understanding of thought based on the Taxation Law and Regulation, but also demands the ability or technical skills how to calculate the amount of tax payable [1]. While (Tambun, 2016) states that the existence of good taxation knowledge can help improve taxpayer compliance with the importance of paying taxes and taxpayers can do so in accordance with tax legislation. If the taxpayer does not have knowledge of tax regulations and processes, the taxpayer does not determine his behavior properly [2].

This is supported by research conducted by Kurnia (2012), Yulsiati (2015), Arwadi et al. (2015), Nugroho et al. (2016), Endrik (2014), Napitulu Nurul (2015) which examined the knowledge and understanding of individual taxpayers that had a positive and significant effect on tax compliance [3]-[8]. Meanwhile, this research is different from the one conducted by Nurlaela S (2014), Monica C.A. (2015), which examines knowledge and understanding that does not have a significant effect on the level of tax compliance [9], [10] .

In addition to the knowledge and understanding of taxpayers, the level of tax compliance is also influenced by the taxpayer's awareness of tax obligations that must be paid to the state treasury. Awareness of taxpayers related to the views or thoughts of taxpayers in determining their behavior (perceived behavioral belive) in compliance to pay taxes [11]. The higher the level of awareness of taxpayers, then they will be able to determine actions that are in accordance with tax laws so that they have a high level of compliance [12].

This is supported by research conducted by Annisa and Sulaikha (2011), Kurnia (2012), Monica C.A. (2015), which examines the effect of awareness of paying taxes that have an effect on tax compliance [3], [9], [13]. While this study is different from Nurlaela (2014), Yulsiati H (2015), Arwadi et al. (2015), Nugroho et al. (2016) who examined similar things where the effect of paying tax awareness did not have a significant effect on tax compliance [4]-[6], [10].

The socialization factor also influences tax compliance. Without the socialization of tax regulations, taxpayers will not know and understand the procedures for fulfilling their tax obligations. Awareness of the obligation to pay taxes will also decrease because taxpayers do not know about the latest regulations in the field of taxation. Taxpayers partially understand that Regulation Number 23 of 2018 is a rule related to the reduction in income tax rates from $1 \%$ to $0.5 \%$. But actually not limited to that, there are a number of other important things that escaped the understanding of taxpayers. For example, taxpayers can choose to use the method of calculating the amount of tax payable, the existence of the period of use of the final tax rate, and so forth. This problem arises because of the lack of socialization to taxpayers. So that in the long term, implementation will cause problems related to compliance with paying taxes.

In addition, taxation socialization has a big influence on increasing the number of registered taxpayers and increasing knowledge and understanding of taxpayers so that it automatically increases state revenue from the taxation sector [14].

This is supported by research conducted by Faizin et al. (2016), Kusuma and Erma (2018), Setyabudi (2017), Boediono, S and Sri H. (2018), which examines the effect of socialization that has an influence on tax compliance [15]-[18]. While this research differs by Winerungan, (2013), which states that the lack of intensive socialization provided by the 
government will have an impact on the low knowledge and understanding of taxpayers so that it affects the tax compliance [14].

The principle of justice is one that is often an important consideration in building a taxation system. A taxation system can be successful if the community believes that the tax collected by the government has been imposed fairly, and everyone pays according to his ability.

Sekar (2018) and Yesi and Raja (2014) examined the justice variable as having an influence on taxpayer compliance [19], [20] while the results in this study are not in line with those conducted by Jackson and Milliron (1986) and Richardson (2006) which state that the inconsistency between justice and taxpayer compliance is due to the multidimensional nature of tax justice as a compliance variable [21], [22].

The main purpose of this research is to find out how the influence of knowledge and understanding, awareness, socialization, and justice on tax-paying compliance with respect to the issuance of Government Regulation Number 23 of 2018 for entrepreneur taxpayers in the City of Belopa, Luwu Regency.

\section{Research Methods}

In this study, researchers used qualitative and quantitative research approaches. So, researchers will describe and analyze phenomena, events, social activities, attitudes, and thoughts of respondents individually or in groups. Then to get more specific, clear, detailed results and test the theory, the researchers used data collection techniques by means of observation, literature review, questionnaires, and structured interviews and then processed using the SPSS 21.0 software application. By combining this research approach, it is hoped that conclusions and suggestions can be useful for the government, taxpayers, and future researchers.

\section{Research Findings}

Table 2. Combined Testing (F-test)

\begin{tabular}{cccccc}
\hline $\begin{array}{c}\text { Dependent } \\
\text { Variable }\end{array}$ & Independent & \multicolumn{2}{c}{ Summary Model } & \multicolumn{2}{c}{ Anova } \\
& Variable & R & R Square & F-count & Sig \\
\hline & Knowledge and Understanding (X1) & & & & \\
$\begin{array}{c}\text { Tax Paying } \\
\text { Compliance } \\
(Y)\end{array}$ & Awareness (X2) & & & & \\
& Socialization (X3) & 0.467 & 0.218 & 6.623 & 0.000 \\
& Justice (X4) & & & & \\
F-table statistic & & 0.794 & & & \\
\hline
\end{tabular}


Based on the F-Test results obtained from the output of SPSS 21.0, the Correlation Coefficient $(\mathrm{R})$ value is 0.467 . It shows that there is a fairly strong relationship between knowledge and understanding (X1), awareness (X2), socialization (X3), and Justice (X4) in combination with paying tax compliance (Y) in Belopa City, Luwu Regency.

The coefficient of determination ( $\mathrm{R}$ square) of 0.218 states that the influence of knowledge and understanding (X1), awareness (X2), socialization (X3) and justice (X4) simultaneously influence tax-paying compliance $(\mathrm{Y})$ of $21.8 \%$. While the remaining $78.2 \%$ is still influenced by other variables not included in this study.

Then the F-count obtained based on the test results was 6.623 with a significance level of 0,000 , while the F-table obtained from the statistical table of 0.794 was used as a comparison. If the F-count is greater than the F-table, the independent variable has an influence on the dependent variable, and if the significance value is below 0.05 , the independent variable has a significant effect on the dependent variable.

The results obtained in this study are the F-count (6.623) is greater than the F-table (0.794) and the significance $(0.000)$ is less than 0.05 . This shows that the F-Test or simultaneously, the independent variable of knowledge and understanding (X1), awareness (X2), socialization (X3), and Justice (X4) has signed on the dependent variable of tax-paying compliance $(\mathrm{Y})$.

Table 3. Partial Testing (T-Test)

\begin{tabular}{ccccc}
\hline $\begin{array}{c}\text { Independent } \\
\text { Variable }\end{array}$ & $\begin{array}{c}\text { Coefficient } \\
\text { Regression } \\
\text { (B) }\end{array}$ & $\begin{array}{c}\text { Standardized } \\
\text { coefficients } \\
\text { Beta }\end{array}$ & T-count & Sig \\
\hline Knowledge and Understanding & 0.202 & 0.190 & 2.082 & 0.040 \\
(X1) & 0.328 & 0.257 & 2.807 & 0.006 \\
Awareness (X2) & 0.936 & 0.799 & 2.636 & 0.010 \\
Socialization (X3) & -0.608 & -0.560 & -1.845 & 0.068 \\
Justice (X4) & \multicolumn{3}{c}{0.603} \\
Constanta (b0) & \multicolumn{3}{c}{0.6770} \\
T-table statistic &
\end{tabular}

Based on partial testing or T-Test seen from the table above shows that knowledge and understanding, awareness, and socialization affect tax compliance while the justice variable has no effect on tax-paying compliance in Belopa City. This can be known by 2 (two) ways, firstly by looking at the significance value greater or smaller than 0.05 . If the significance value is less than 0.05 , then the variable is significant, secondly, by comparing the value of $t$ count with t-table. If the t-count is greater than the t-table statistics, it can be interpreted that it is significant.

The significant value of the knowledge and understanding variable (X1) was 0.040 , the awareness variable (X2) was 0.006 , and the socialization variable (X3) was 0.010 . While the justice variable (X4) was 0.068 , from these results, it shows that partially the knowledge and understanding variables (X1), the awareness variable (X2), and the socialization variable (X3) have a significant effect while the justice variable has no significant effect seen from the significant value larger than 0.05 .

While the comparison of the T-count of knowledge and understanding variables (2.082) is greater than the T-table $(0.6770)$, the awareness variable $(2.807)$ is greater than the T-table $(0.6770)$. Furthermore, the socialization variable with a T-test of 2.636 is greater than the Ttable of 0.6770 . The justice variable has T-count $(-1.845)$ smaller than T-table $(0.6770)$. The 
analysis showed that of the three variables that had a significant effect, it turned out that the awareness variable had the most dominant influence in increasing tax-paying compliance in the City of Belopa.

Based on the results of the F-test and t-Test described above, the results of testing this research model can be presented in the following figure:

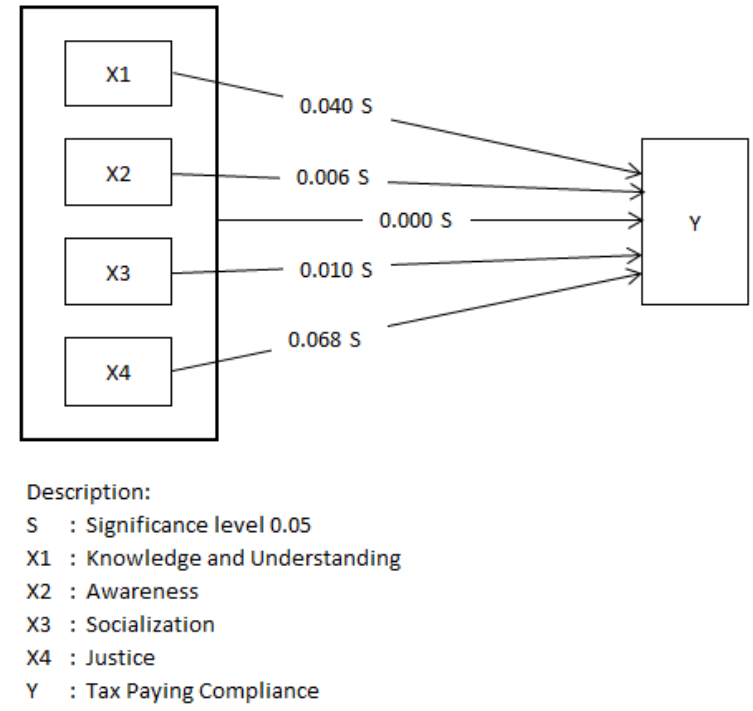

Fig. 1. The Results of Testing The Model of The Influence of Knowledge and Understanding, Awareness, Socialization, and Fairness Towards Tax Compliance

\section{Discussion}

\subsection{Effect of Knowledge and Understanding (X1) on Tax Paying Compliance (Y) in Belopa City}

Based on the results of hypothesis testing with statistical analysis using the SPSS 21.0 program, it is known that the knowledge and understanding variables have a positive and significant effect on tax compliance in Belopa City. Where the significance level (0.040) is smaller than 0.05 , and the T-test value (2.094) is greater than the T-table, which is only 0.6770 . It proves that the first hypothesis which states knowledge and understanding has a positive and significant effect on tax compliance in Belopa City is accepted. This means that if the taxpayers have knowledge and understanding of applicable regulations, the taxpayer will make a major contribution to increasing tax-paying compliance. Meanwhile, if the knowledge and understanding of taxpayers are lacking, the level of tax-paying compliance also tends to decrease.

Tambun (2016) states that the presence of good taxation knowledge can help improve taxpayer compliance with the importance of paying taxes, and taxpayers can do it in accordance with tax legislation. If the taxpayer does not have knowledge of tax regulations and processes, the taxpayer does not determine his behavior properly [2]. 
This is supported by research by Kurnia et al. (2012), Yulsiati (2015), Arwadi (2015), Nugroho et al. (2016), Endrik Nur S (2014), Nurul Asyah N (2015) [3]-[8]. Researching on the knowledge and understanding of individual taxpayers has a positive and significant effect on tax-paying compliance. While this research is different from the others conducted by Nurlaela (2014), Monica C.A. (2015), which examines knowledge and understanding, does not have a significant effect on the level of tax-paying compliance [9], [10].

\subsection{Effect of Awareness (X2) Against Tax Paying Compliance (Y) in the City of Belopa}

Based on the results of hypothesis testing with statistical analysis using the SPSS 21.0 program, it is known that the awareness variable has a positive and significant effect on tax compliance in Belopa City. Where the significance level $(0.006)$ is smaller than 0.05 , and the value of T-count (2.884) is greater than the T-table (0.6770). This proves that the second hypothesis stating that awareness has a positive and significant effect on tax compliance in Belopa City is accepted. If the awareness of taxpayers increases and aware of their obligations as citizens in paying taxes, it will make a major contribution to increasing taxpaying compliance.

Awareness of taxpayers related to the perspective or thought of taxpayers in determining their behavior (perceived behavioral believe) in terms of compliance to pay taxes. Nalendro \& Isgiyarta, (2014) stated that the higher the level of awareness, the higher the level of compliance with tax laws that would be able to determine the level of compliance [12].

Awareness of individual taxpayers in meeting obligations will increase compliance with individual taxpayers. Taxpayers who realize that taxes are a source of income of a region will contribute to the development and progress of the area. Conscious taxpayers will always try to fulfill their obligations because they understand that if they do not pay taxes, it will have an impact on the financial resources of a region that directly impedes development.

In the results of this study, the awareness variable had the biggest contribution to increase tax compliance. This is supported by several previous studies, which also agreed that awareness has an important role in growing the level of tax-paying compliance. Among the research conducted by Annisa and Sulaikha (2011), Kurnia et al. (2012), Monica C.A. (2015), which examines the effect of awareness of paying taxes, influence tax compliance [3], [9], [13]. While this research is different from Nurlaela (2014), Yulsiati (2015), Arwadi (2015), Nugroho et al. (2016) who examined similar things where the influence of paying tax awareness did not have a significant effect on tax compliance [4]-[6], [10].

\subsection{Effects of Socialization (X3) on Tax Paying Compliance (Y) in the City of Belopa}

Based on the results of hypothesis testing with variable analysis using the SPSS 21.0 program, it can be seen that the socialization variable has a positive and significant effect on tax compliance in Belopa City. Where the level of significance (0.010) is smaller than 0.05, and the value of T-test (2.655) is greater than the value of T-table (0.6770). This proves that the third hypothesis, which states that socialization has a positive and significant effect on tax compliance in the City of Belopa is accepted. This means that if the socialization is carried out well and is often done, it will contribute very well in improving tax-paying compliance. But on the contrary, if the socialization is carried out incorrectly and irregularly, then it will have an impact on decreasing the level of compliance to pay taxes or not paying taxes at all. 
Taxation socialization is an effort or concrete action related to the notification of taxation information to taxpayers, both individuals and business entities in order to comply with tax regulations that have been set by the government. The Directorate General of Taxes in Faizin (2016) states that the socialization is an effort made by the Directorate General of Taxes through various methods to provide information related to all regulations and activities related to taxation so that it can be carried out by taxpayers, both individuals and business entities [15].

Dharma and Suarda (2014), stated that in attribution theory, one's behavior in fulfilling tax obligations is influenced by socialization factors. Socialization can be carried out through counseling, seminars, and other communication media such as advertisements [23]. Winerungan (2013) states that taxation socialization can increase the number of taxpayers and can increase compliance from taxpayers so that automatically state revenues from the taxation sector will increase [14].

In this study, the socialization variable has a big role in increasing tax-paying compliance for taxpayers in the City of Belopa. These results are in line with research conducted by Faizin et al. (2016), Kusuma and Erma W. (2018), Setyabudi (2017), Boediono, S and Sri H. (2018), who stated socialization has an influence on taxpayer compliance [15]-[18]. While this research is somewhat different conducted by Winerungan (2013). Where she states that the lack of intensive socialization given will have an impact on the low knowledge and understanding of taxpayers [14].

\subsection{Effect of Justice (X4) on Tax Paying Compliance (Y) in the City of Belopa}

Based on the results of hypothesis testing with statistical analysis using the SPSS 21.0 program, it is known that the justice variable does not have a positive and significant effect on tax-paying compliance in the City of Belopa. Where the level of significance $(0.068)$ is greater than 0.05 , and the value of the T-test $(-1.845)$ is smaller than the T-table value (0.6770). This proves that the fourth hypothesis stating that justice has a positive and significant effect on tax compliance in Belopa City is rejected.

The taxpayer's perception of the fairness of the taxation system in a country will affect the implementation of taxation in that country. This perception influences tax compliance behavior and tax avoidance behavior. The community will tend to be disobedient and avoid tax obligations if the community considers the current tax system to be unfair.

Mardiasmo (2002), in associated with legal objectives to achieve justice, regulations and implementation of tax collection must be fair. Fair in regulations means to impose taxes in general and equitably, and be adjusted to the capabilities of each taxpayer [24]. While fair in implementation is giving taxpayers the right to file an objection, delay in payment of taxes, and so forth. McGee (2006) explains that tax evasion is considered an ethical thing because of the lack of fairness in the use of money sourced from taxes, corruption of government officials, and do not get a reward/influence over the tax paid. This causes a decrease in state revenue and causes public distrust in government institutions [25].

In this study, the justice variable has no effect on the level of tax-paying compliance. Taxpayers prefer the principle of convenience in calculating the amount of tax payable. Most taxpayers realize that government regulation number 23 of 2018 is more profitable for taxpayers with a total income of more than 360 million in one year. Therefore, the justice variable in this study did not make a major contribution to increase tax compliance in the City of Belopa. 
These results are not in line with research conducted by Sekar (2018) and Yesi and Raja (2014), examining the variable of justice has an influence on taxpayer compliance [19], [20]. While the results in this study are in line with those conducted by Jackson and Milliron (1986) and Richardson (2006), stating that the inconsistency between justice and taxpayer compliance is due to the multidimensional nature of tax justice as a compliance variable [21], [22].

Cristensen et al. in Azmi and Perumal (2008) state that justice is difficult to define because four main problems namely, justice related to dimensional problems, justice can be defined at the individual or group level, justice related to complexity, and lack of justice can cause non-compliance to pay taxes [26].

\section{Conclusion and Suggestion}

\subsection{Conclusion}

From the results of multiple regression analyzes that have been carried out, conclusions can be drawn including:

a. Knowledge and understanding variables have a positive and significant effect on taxpaying compliance with respect to Government Regulation Number 23 of 2018 in the City of Belopa, Luwu Regency.

b. Awareness variable has a positive and significant effect on tax-paying compliance with respect to Government Regulation Number 23 of 2018 in the City of Belopa, Luwu Regency.

c. The socialization variable has a positive and significant effect on tax-paying compliance with respect to Government Regulation Number 23 of 2018 in the City of Belopa, Luwu Regency.

d. The justice variable has a negative and not significant effect on tax-paying compliance in connection with Government Regulation Number 23 of 2018 in the City of Belopa, Luwu Regency.

e. From the results of testing the hypothesis of knowledge and understanding, awareness, socialization, and justice simultaneously affect the tax-paying compliance in connection with Government Regulation Number 23 of 2018 in the City of Belopa, Luwu Regency.

\subsection{Suggestion}

For the Government. The government must increase tax socialization regarding tax rates and tax provisions that apply in Indonesia so that the understanding and awareness of taxpayers about taxation is increasing.

For taxpayers. For taxpayers who are respondents in this study, it is better to understand the functions and objectives of taxation so that they can participate maximally in the development of the State.

For Future Researchers. Future studies can use other independent variables such as tax reform, sanctions, tax amnesty, compliance costs, attitudes, tax accountability, or the impact 
of implementing Government Regulation Number 23 of 2018, which is more clear. Future studies are expected to be able to take a larger sample and not only the Individual Taxpayer in the City of Belopa, so that better research results can be obtained.

\section{References}

[1] Supriyati. S.: Pengaruh pengetahuan pajak dan persepsi wajib pajak terhadap kepatuhan wajib pajak. The Indonesian Accounting Review. vol. 1, no. 1, pp. 27-36 (2011).

[2] Tambun. S.: Anteseden Kepatuhan Wajib Pajak Orang Pribadi dan Moderasi Sosialisasi Perpajakan. Jurnal Media Akuntansi Perpajakan, vol. 1, no. 1 (2016).

[3] Kurnia. W. M.: Analisis Faktor-Faktor Yang Mempengaruhi Wajib Pajak Orang Pribadi Dalam Memenuhi Kewajiban Membayar Pajak (Studi Kasus Pada Kantor Pelayanan Pajak Pratama Semarang Candisari),. Diponegoro Journal Of Accounting. vol. 1, no. 2 (2012).

[4] Yulsiati. H.: Analisis Pengaruh Sikap, Kesadaran Wajib Pajak, Pengetahuan Perpajakan dan Pemahaman Peraturan Perpajakan Terhadap Kepatuhan Wajib Pajak dalam Membayar Pajak Bumi dan Bangunan di Kecamatan Kemuning Kota Palembang. Jurnal Akuntanika. vol. 2, no. 1, pp. 1-16 (2015).

[5] H Arwadi, Malikah. A, and Mawardi M. C.:Pengaruh Efektifitas Sistem Perpajakan, Kesadaran Membayar Pajak, Pengetahuan Dan Pemahaman Mengenai Peraturan Pajak, Serta Tingkat Kualitas Pelayanan Fiskus Terhadap Kemauan Membayar Pajak Wajib Pajak Orang Pribadi Di Kota Malang (Studi Kasus Pada Kantor (2015).

[6] Nugroho. A, Andini. R, and Raharjo. K.: Pengaruh kesadaran wajib pajak dan pengetahuan perpajakan wajib pajak terhadap kepatuhan wajib pajak dalam membayar pajak penghasilan (studi kasus pada KPP Semarang Candi). Journal Of Accounting. vol. 2, no. 2 (2016).

[7] Endrik. N. S.: Pengaruh Pengetahuan Pajak, Kemudahan Pajak dan Keadilan Pajak terhadap Kepatuhan Formal Wajib Pajak UMKM PP Nomor 46 Tahun 2013 di KPP Pratama Surabaya Gubeng. Universitas Airlangga Surabaya (2014).

[8] Nurul. A. N.: Pengaruh Sosialisasi dan Pengetahuan Perpajakan terhadap Kemauan Membayar Pajak dengan Kesadaran Membayar Pajak sebagai Variabel Intervening (Studi pada WPOP PPh Pasal 29 di KPP Pratama Pekanbaru Senapelan). Jurnal: Jom FEKON, vol. 2, no. 2 (2015).

[9] Monica C. A.: Analisis Faktor-faktor yang mempengaruhi kepatuhan wajib pajak orang pribadi dalam membayar pajak. CALYPTRA. vol. 4, no. 2, pp. 1-15 (2015).

[10] ]Nurlaela. S.: Pengaruh Pengetahuan dan Pemahaman, Kesadaran, Persepsi terhadap Kemauan membayar Pajak Wajib Pajak Orang Pribadi yang Melakukan Pekerjaan Bebas. Paradigma, vol. 11, no. 2 (2014).

[11] Suyanto. Y. H.: Kepatuhan Wajib Pajak Orang Pribadi: Studi Aspek Pengetahuan, Kesadaran, Kualitas Layanan dan Kebijakan sunset policy. Ekonomi dan Bisnis (2018).

[12] Nalendro. T. I. and Isgiyarta.: Faktor-faktor yang mempengaruhi kepatuhan membayar pajak wajib pajak orang pribadi yang berwirausaha dengan lingkungan sebagai variabel moderasi. Diponegoro Journal of Accounting. vol. 3, no. 3, pp. 1-75 (2014).

[13] Annisa Z. N.: Analisis Pengaruh Kesadaran Perpajakan, Sikap Rasional, Lingkungan, Sanksi Denda dan Sikap Fiskus terhadap Kepatuhan Wajib Pajak (Studi Empiris pada WPOP di Wilayah KPP Pratama Semarang) (2011).

[14] Winerungan. O.: Sosialisasi Perpajakan, Pelayanan Fiskus Dan Sanksi Perpajakan Terhadap Kepatuhan Wpop Di Kpp Manado Dan Kpp Bitung. Jurnal EMBA, vol. 1, no. 3, pp. 960-970 (2013).

[15] Faizin. M. R and Ruhana. I.: Pengaruh Sosialisasi, Pemahaman, dan Kesadaran Prosedur Perpajakan terhadap Kepatuhan Wajib Pajak (Studi pada Wajib Pajak Orang Pribadi PBB Perdesaan dan Perkotaan di Desa Mojoranu Kabupaten Bojonegoro) Bangunan Perdesaan dan Perkotaan di Desa Mojoranu Ka. Jurnal Mahasiswa Perpajakan. vol. 9, no. 1 (2016).

[16] Kusuma. D. W and Wati. E.: Pengaruh Sosialisasi Perpajakan Terhadap Kepatuhan Wajib Pajak Dengan Pengetahuan Perpajakan Sebagai Variabel Intervening (Studi Pada Wajib Pajak Orang 
Pribadi di KPP Pratama Kebumen). Nominal, Barometer Riset Akuntansi dan Manajemen. vol. 7, no. 1, pp. 33-54 (2018).

[17] Setyabudi, M.: Pengaruh Sosialisasi Perpajakan, Pengetahuan Perpajakan, sanksi pajak PPh Final (Implementasi PP Nomor 46 Tahun 2013) terhadap Kepatuhan Wajib Pajak Orang Pribadi (Studi Emperis pada Wajib Pajak yang Terdaftar di KPP Pratama Surakarta) (2014).

[18] Boediono. G. T, Sitawati. R, and Harjanto.S.: Analisis Pengaruh Sosialisasi Perpajakan Terhadap Kepatuhan Wajib Pajak Dengan Kesadaran Sebagai Variabel Mediasi. Jurnal Penelitan Ekonomi dan Bisnis. vol. 3, no. 1, pp. 22-38 (2018).

[19] Sekar. A. F.: Persepsi Keadilan, Sistem Perpajakan dan Diskriminasi terhadap Etikan Pengelapan Pajak. Jurnal Ilmu Akuntansi vol. 11, no. 1 (2018).

[20] Yesi. Y, M.B and Raja Adri Satriawan. S.: Pengaruh keadilan, Norma Ekspektasi, Sanksi dan Religiusitas terhadap niat dan ketidak patuhan pajak. Akuntabilitas. vol. VII, no. 3, (2014).

[21] Jackson. B. R and Milliron. V. C.: Tax compliance research: Findings, problems, and prospects," Journal of accounting literature. vol. 5, no. 1, pp. 125-165 (1986).

[22] Richardson. G.: The impact of tax fairness dimensions on tax compliance behavior in an Asian jurisdiction: The case of Hong Kong. Int'l Tax J., vol. 32, p. 29 (2006).

[23] Dharma. A. S, Esa Gede Pani Ketut.: Pengaruh Kesadaran Wajib Pajak, Sosialisasi Perpajakan, Kualitas Pelayanan pada Kepatuhan Wajib. E-Jurnal Akuntansi Universitas Udayana (2014).

[24] Mardiasmo, Akuntansi Sektor Publik. Yogyakarta: Andi (2002).

[25] McGee. R. W.:Three views on the ethics of tax evasion. Journal of Business Ethics. vol. 67, no. 1, pp. 15-35 (2006).

[26] Azmi. A. A. C and Perumal. K. A.: Tax fairness dimensions in an Asian context: The Malaysian perspective. International Review of Business Research Papers. vol. 4, no. 5, pp. 11-19 (2008) 